\title{
Pearl millet cultivation with brackish water and organic fertilizer alters soil properties
}

\author{
O cultivo do milheto com água salobra e adubação orgânica altera as \\ características do solo
}

Cleyton de Almeida Araújoํㅜ (1) , Jaciele Beserra de Lira² (1) , André Luiz Rodrigues Magalhães $^{3}$ (1) , Thieres George Freire da Silva ${ }^{4}$ (1) , Glayciane Costa Gois ${ }^{1 *}$ (1) , Alberício Pereira de Andrade ${ }^{3}$ (1) , Gherman Garcia Leal de Araújo ${ }^{5}$ (1) , Fleming Sena Campos ${ }^{5}$ (1)

\begin{abstract}
${ }^{1}$ Universidade Federal do Vale do São Francisco (UNIVASF), Petrolina, PE, Brazil
¿Universidade Federal da Paraíba (UFPB), Areia, PB, Brazil

${ }^{3}$ Universidade Federal Rural de Pernambuco (UFRPE), Garanhuns, PE, Brazil

${ }^{4}$ Universidade Federal Rural de Pernambuco (UFRPE), Serra Talhada, PE, Brazil

${ }^{5}$ Empresa Brasileira de Pesquisa Agropecuária (Embrapa), Petrolina, PE, Brazil

*Correspondent: glayciane gois@yahoo.com.br
\end{abstract}

Received

August 24, 2021.

Accepted

November 22, 2021.

Published

December 9, 2021.

www.revistas.ufg.br/vet visit the website to get the how to cite in the article page.

\begin{abstract}
Semi-arid regions are characterized by high evapotranspiration and low rainfall, favoring the accumulation of salts when irrigated with brackish water. The aim of this study was to evaluate the effect of pearl millet cultivation with brackish water levels and fertilized with organic fertilizer on the chemical and physical properties of the soil. A split plot randomized block design was adopted, in a factorial arrangement, with three repetitions. Plots consisted of four irrigation levels $(25,50,75$ and $100 \%$ crop evapotranspiration) and subplots consisted of four levels of organic fertilizer (0; 15; 30 and $\left.45 \mathrm{Mg} \mathrm{ha}^{-1}\right)$. At the end of the pearl millet production cycle, soil was collected from layers 0-0.20 m and 0.20-0.40 m, for physical (soil bulk density, particle density and porosity) and chemical (EC, $\mathrm{pH}, \mathrm{K}, \mathrm{Na}, \mathrm{Ca}$, $\mathrm{Mg}, \mathrm{H}+\mathrm{Al}, \mathrm{SB}, \mathrm{CEC}, \mathrm{V})$ properties. There was no effect of interaction of brackish water levels and organic fertilizer levels on soil chemical properties. Brackish water reduced potassium on layer $0.20-0.40 \mathrm{~m}$. A negative linear effect was found for density in the $0.20-0.40 \mathrm{~m}$ layer under different levels of organic fertilizer. Brackish water levels and organic fertilizer levels in the cultivation of pearl millet does not alter soil chemical and physical properties at the $0-0.20$ m layer. However, the use of brackish water reduces the concentration of potassium in the soil and the application of organic fertilizer reduces soil density at the 0.20-0.40 m layer.
\end{abstract}

Key words: Base saturation; Biosaline agriculture; Pennisetum glaucum (L.) R. Br.

\section{Resumo}

Regiões semiáridas são caracterizadas pela elevada 
evapotranspiração e baixa precipitação pluvial, favorecendo o acúmulo de sais quando irrigado com água salobra. Objetivouse avaliar o efeito do cultivo de milheto com níveis de água salobra e fertilização orgânica nas propriedades químicas e físicas do solo. Adotou-se o delineamento de blocos ao acaso, com arranjo fatorial, em parcelas subdivididas, com três repetições. As parcelas foram constituídas por quatro lâminas de irrigação $(25,50,75$ e 100\% da evapotranspiração da cultura) e as subparcelas foram compostas por quatro níveis de fertilização orgânica $\left(0 ; 15 ; 30\right.$ e $\left.45 \mathrm{Mg} \mathrm{ha}^{-1}\right)$. No final do ciclo de produção do milheto, o solo foi coletado nas camadas de $0-0,20$ e 0,20-0,40 m, para aspectos físicos (densidade do solo, densidade de partículas e porosidade) e químicos ( $\mathrm{CE}, \mathrm{pH}, \mathrm{K}, \mathrm{Na}$, $\mathrm{Ca}, \mathrm{Mg}, \mathrm{H}+\mathrm{Al}, \mathrm{SB}, \mathrm{CTC}, \mathrm{V})$. Não houve interação entre a água salobra e a fertilização orgânica nas propriedades químicas do solo. A água salobra reduziu o potássio na camada de 0,20-0,40 $\mathrm{m}$. Observou-se efeito linear negativo para densidade na camada 0,20 - 0,40 m sob níveis de fertilização orgânica. Níveis de água salobra e fertilizante orgânico no cultivo do milheto não altera as propriedades químicas e físicas do solo na camada de 0-0,20 m. Porém, o uso de água salobra reduz a concentração de potássio no solo e a aplicação de fertilização orgânica reduz a densidade do solo na camada de 0,20-0,40 m.

Palavras-chave: Agricultura biossalina; Pennisetum glaucum (L.) R. Br; Saturação por bases

\section{Introduction}

The Brazilian Northeast has $70 \%$ included in the semi-arid region ${ }^{(1)}$. This region is characterized by poor distribution of rainfall and high evaporation rates. Due to these characteristics and the scarce rainfall, water sources are considered insufficient in these regions ${ }^{(2)}$. Despite high levels of soluble salts in water resources in semi-arid regions, in the absence of other sources, brackish and saline water represent the only alternative to be used by farmers both for irrigation and for watering herds(3).

Soils in the semi-arid region contain high level of sodium, favoring sodium solubilization in groundwater ${ }^{(4)}$. However, the use of brackish water promotes changes in the soil physical-mechanical and chemical properties. Brackish water can act in the dispersion of soil clays, resulting in pore clogging due to excess sodium, which provides an increase in soil compaction, reducing water infiltration ${ }^{(5,6)}$. In addition, the excess of salt ions impairs growth, respiration, root expansion, in addition to water uptake and $\mathrm{CO}_{2}$ fixation by the plant ${ }^{(7)}$. Increasing concentrations of salts and exchangeable sodium in the soil can cause soil infertility, increasing susceptibility to erosion, in addition to the contamination of underground water reserves and groundwater ${ }^{(8)}$.

The use of organic compounds of animal origin as organic fertilizer is a useful and economic practice widely used by farmers in the Brazilian semi-arid region. This practice mitigates the effect of soil salinity, through the production of humic acids and 
organic acids, promoting an increase in carbonate solubilization $(9,10,11)$, providing a delay in the effect of adding salts to the soil by irrigation and leaching of these salts during the rainy season in semi-arid regions ${ }^{(12)}$. According to Silva et al.(13), organic fertilizer incorporated into the soil improves the physical structure, reducing the soil mass, which favors soil porosity and electrical conductivity. Furthermore, organic fertilization attenuates the harmful effects of salts in the plant root environment. Souza et al.(14) argue that humic substances released by the decomposition of sources used as organic fertilizers stimulate the uptake of water and nutrients by plants in brackish environments.

In this context, the use of brackish water for forage production is a viable alternative when combined with soil management techniques ${ }^{(15)}$ which allows the reorganization and availability of the mineral component of the soil, favoring crop development and a direction of water considered limiting for production of vegetables. Thus, the use of brackish water and the application of levels of organic fertilizer during crop production becomes a sustainable strategy for food production in dryland regions, specifically in the semi-arid region of Northeast Brazil(16).

Among the diversity of forage available to feed herds in semi-arid regions, Pearl millet (Pennisetum glaucum) has good yield and nutritional quality, short cycle and regrowth capacity $(17,18)$ in addition to tolerance to saline stress ${ }^{(19,20)}$, characteristics that make pearl millet a sustainable alternative for cultivation in biosaline systems.

The aim of this study was to evaluate the effect of pearl millet cultivation with brackish water levels and organic fertilizer levels on the chemical and physical properties of the soil.

\section{Material and methods}

\section{Experimental site}

The experiment was conducted in the Prospecting Area in Biosaline Studies, belonging to Embrapa Semiárido, Petrolina, state of Pernambuco, Brazil (latitude 98'8.9" S, longitude 40¹8'33.6" W, altitude $373 \mathrm{~m}$ ) from March to June 2018.

The climate is hot semi-arid, BSwh' according to Köppen and Geiger ${ }^{(21)}$, with an average annual rainfall of $400 \mathrm{~mm}$. Environmental conditions were monitored daily during the experimental period by an automatic weather station, with a mean temperature of 25.6 ${ }^{\circ} \mathrm{C}$, mean daily evapotranspiration of $4.1 \mathrm{~mm} \mathrm{~d}^{-1}$ and total rainfall of $140.8 \mathrm{~mm}$ (Figure 1), however, rainfall was concentrated between March and April.

\section{Pearl millet}

The experiment was developed with pearl millet variety ADR 300 . Sowing was carried out in March 2018, in furrows, with an average of 40 seeds per row meter, at a depth of $0.01 \mathrm{~m}$. Fifteen days after emergence, thinning was done to maintain 15 plants per row meter. Manual weeding was conducted at 30 DAS (days after sowing), followed by a preventive application of insecticide against fall armyworm (Spodoptera frugiperda) at 40 and 60 DAS. 


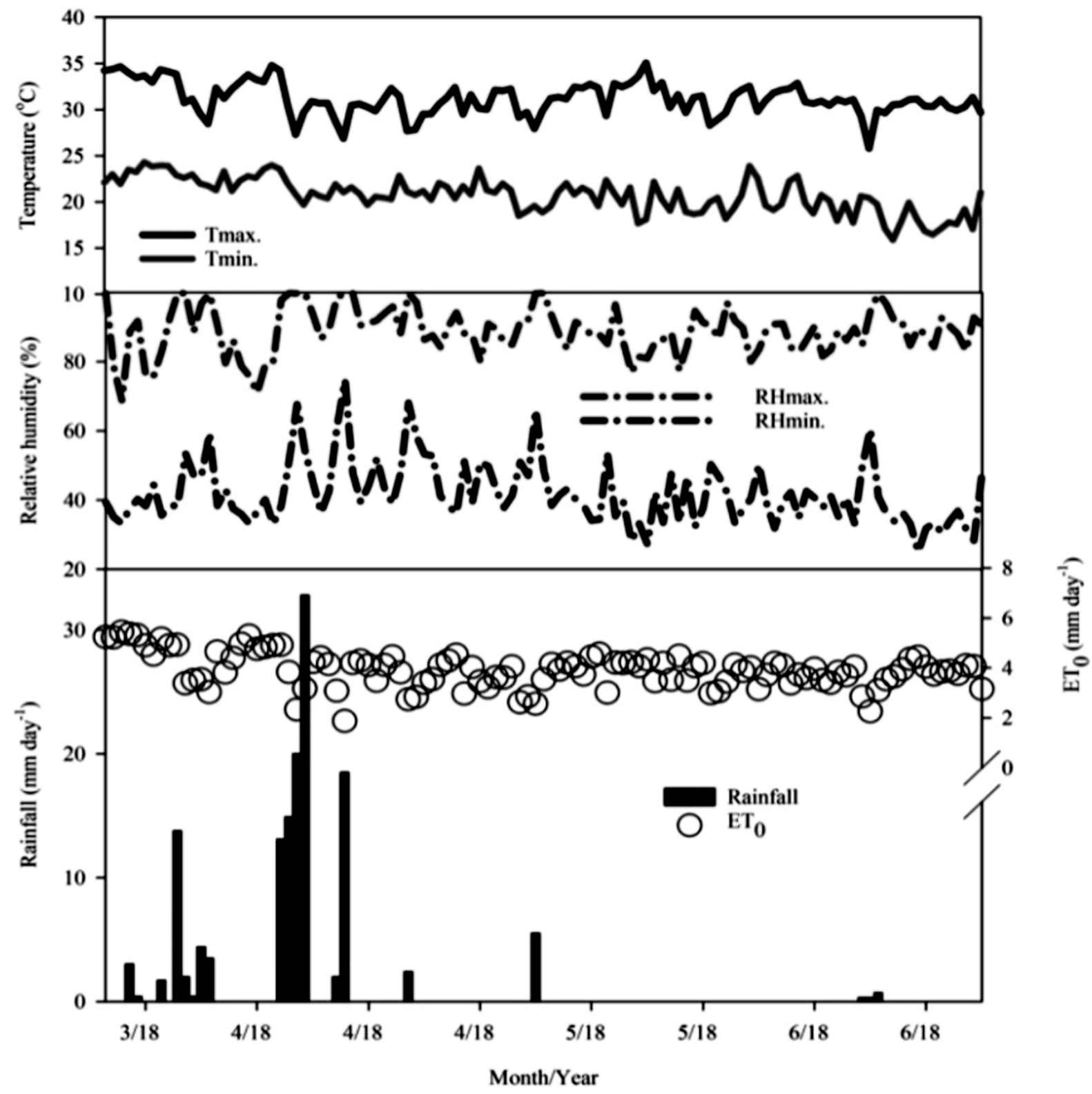

Figure 1. Weather variables along the experimental period in the prospecting area in biosaline studies, Embrapa Semiárido, Petrolina, state of Pernambuco, Brazil.

\section{Experimental design}

The experiment was conducted in a split plot randomized block design, with three repetitions. Plots consisted of four irrigation levels with brackish water $(l ; 25,50,75$ and $100 \%$ crop evapotranspiration) and subplots consisted of four levels of organic fertilizer (OF; 0; 15; 30 and $45 \mathrm{Mg} \mathrm{ha}^{-1}$, on a natural matter basis). Each experimental subplot consisted of six planting rows, $6 \mathrm{~m}$ long, $3.6 \mathrm{~m}$ wide and $0.60 \mathrm{~m}$ between rows, totaling 48 subplots.

Samples collection 
Soil samples from the experimental area before planting pearl millet (Figure 2) were collected from the $0-20$, and $20-40 \mathrm{~cm}$ layers for physical and chemical analysis (Table 1). Soil of the experimental area was classified as Acrissols, flat relief, with medium texture ${ }^{(22)}$. Soil was prepared by plowing, harrowing and furrowing before planting.

Table 1. Chemical and physical properties of the soil before planting pearl millet

\begin{tabular}{|c|c|c|c|c|}
\hline \multirow{2}{*}{\multicolumn{3}{|c|}{ Variables }} & \multicolumn{2}{|c|}{$\begin{array}{c}\text { Sample identification } \\
(\mathrm{cm})\end{array}$} \\
\hline & & & $0-20$ & $20-40$ \\
\hline$\overline{E C}$ & $\mathrm{dS} \mathrm{m}^{-1}$ & & 1.33 & 2.20 \\
\hline $\mathrm{pH}$ & - & & 4.60 & 5.70 \\
\hline V & $\%$ & & 64.0 & 50.9 \\
\hline Total C & $\mathrm{g} / \mathrm{kg}$ & & 4.60 & 4.10 \\
\hline $\mathrm{K}$ & $\mathrm{cmol} \mathrm{dm}{ }^{-3}$ & & 0.23 & 0.16 \\
\hline $\mathrm{Na}$ & $\mathrm{cmol} \mathrm{dm}^{-3}$ & & 0.27 & 0.68 \\
\hline $\mathrm{Ca}$ & $\mathrm{cmol} \mathrm{dm}^{-3}$ & & 1.60 & 1.40 \\
\hline Mg & $\mathrm{cmol} \mathrm{dm}^{-3}$ & & 0.60 & 0.60 \\
\hline Al & $\mathrm{cmol} \mathrm{dm}^{-3}$ & & 0.05 & 0.00 \\
\hline $\mathrm{H}+\mathrm{Al}$ & $\mathrm{cmol} \mathrm{dm}^{-3}$ & & 1.50 & 2.70 \\
\hline SB & $\mathrm{cmol} \mathrm{dm}{ }^{-3}$ & & 2.70 & 2.80 \\
\hline CEC & $\mathrm{cmol} \mathrm{dm}^{-3}$ & & 4.20 & 5.60 \\
\hline $\bar{P}$ & $\mathrm{mg} \mathrm{dm}^{-3}$ & & 6.14 & 1.22 \\
\hline $\mathrm{Cu}$ & $\mathrm{mg} \mathrm{dm}^{-3}$ & & 1.07 & 1.65 \\
\hline $\mathrm{Fe}$ & $\mathrm{mg} \mathrm{dm}^{-3}$ & & 21.40 & 23.00 \\
\hline $\mathrm{Mn}$ & $m g d m^{-3}$ & & 18.20 & 14.60 \\
\hline $\mathrm{Zn}$ & $\mathrm{mg} \mathrm{dm} \mathrm{dm}^{-3}$ & & 4.54 & 3.13 \\
\hline \multirow{2}{*}{ Density } & $\mathrm{kg} \mathrm{dm}^{-3}$ & soil & 1.49 & 1.37 \\
\hline & $\mathrm{kg} \mathrm{dm}^{-3}$ & particle & 2.59 & 2.51 \\
\hline Total porosity & & (\%) & 42.40 & 45.41 \\
\hline \multirow{3}{*}{ Granulometry } & $\mathrm{g} \mathrm{kg}^{-1}$ & sand & 808.10 & 721.70 \\
\hline & $\mathrm{g} \mathrm{kg}^{-1}$ & silte & 116.9 & 195.3 \\
\hline & $\mathrm{g} \mathrm{kg}^{-1}$ & clay & 75.00 & 83.00 \\
\hline
\end{tabular}

$\mathrm{EC}=$ electrical conductivity of the saturation extract; $\mathrm{pH}=$ hydrogenionic potential determined in water at a ratio of $1: 2.5 ; \mathrm{V}=$ base saturation; Total $\mathrm{C}=$ total carbon; $\mathrm{K}=$ exchangeable potassium; $\mathrm{Na}=$ exchangeable sodium; $\mathrm{Ca}=$ exchangeable calcium; $\mathrm{Mg}=$ exchangeable magnesium; $\mathrm{Al}=$ exchangeable aluminum; $\mathrm{H}+\mathrm{Al}=$ potential acidity; $\mathrm{SB}=$ sum of bases; $\mathrm{CEC}=$ cation exchange capacity at $\mathrm{pH}$ 7.0; $\mathrm{P}=$ available phosphorus extracted by Mehlich; $\mathrm{Cu}=$ available copper; $\mathrm{Fe}=$ available iron; $\mathrm{Mn}=$ available manganese; $\mathrm{Zn}=$ available zinc 
In the period prior to this experiment, the experimental area was used for sowing pearl millet and its productivity was evaluated in 130 days ( 2 cycles), during the period from September 2017 to January 2018. During this period, the mean rainfall was $0.57 \mathrm{~mm}$ (87 $\mathrm{mm}$ ) and the mean evapotranspiration (ETo) was $5.32 \mathrm{~mm}$. Pearl millet was irrigated with $426 \mathrm{~mm}$ brackish water in the experimental period. During this period, nitrogen fertilization was carried out with $50 \mathrm{~kg} \mathrm{ha}^{-1} \mathrm{~N}$, as urea, applied manually and split into two applications, the first at sowing, with $20 \mathrm{~kg} \mathrm{~N} \mathrm{ha}^{-1}$, and the second, 20 days after

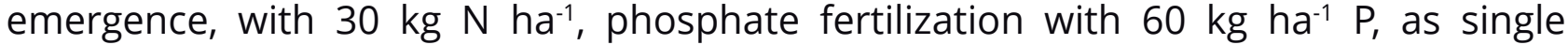
superphosphate, and potassium fertilization with $20 \mathrm{~kg} \mathrm{ha}^{-1} \mathrm{~K}$, as potassium chloride. Fifteen days before sowing, $50 \mathrm{t} \mathrm{ha}^{-1}$ organic matter were applied in the experimental area.

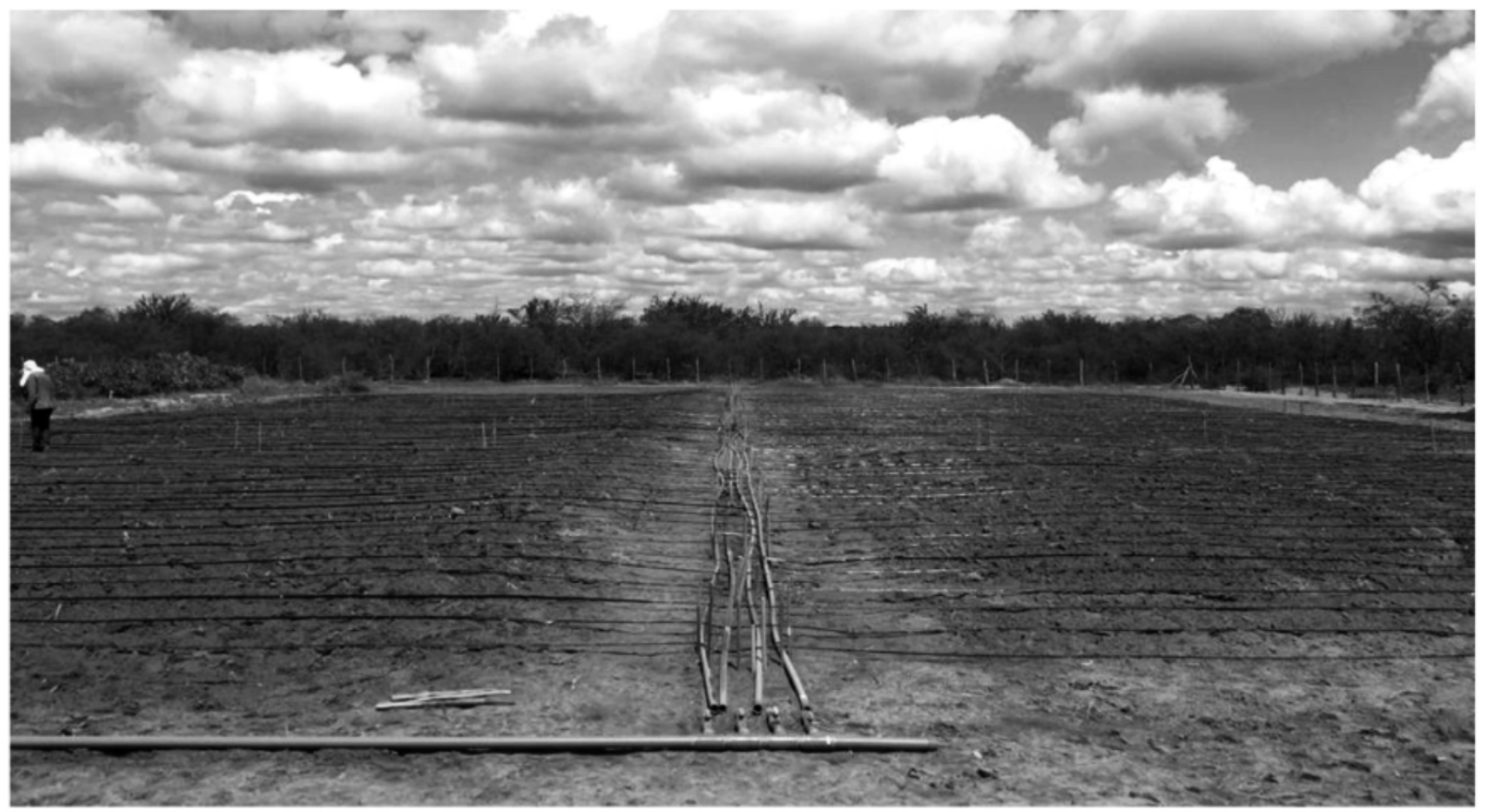

Figure 2. Experimental area before planting Pearl millet

\section{Reference evapotranspiration}

The reference evapotranspiration was calculated according to Allen et al. ${ }^{(23)}$. Water was applied according to crop evapotranspiration (ETC), obtained by multiplying ETo and crop coefficient $(\mathrm{Kc})$. The adopted values of $\mathrm{Kc}$ (initial stage - 0.40; vegetative development stage - 0.68; flowering stage - 1.14; physiological maturity stage - 1.10) were from a study by Lima ${ }^{(24)}$ for the sorghum crop.

\section{Water}

Water used for irrigation came from underground wells with an approximate flow rate of $1500 \mathrm{~L} \mathrm{~h}^{-1}$ and a weekly sample was collected for physical and chemical analysis (Table 2), aiming at possible variations, which was not observed during the experimental period. Water used for irrigation was identified as C3S1 (Table 2), classified with high salinity, low sodium content and moderate hardness (75-150 mg L-1) based on calcium carbonate, according to the classification of Richards ${ }^{(25)}$. 
Table 2. Mean values of the physical and chemical analysis of brackish water used during the experimental period

\begin{tabular}{|c|c|c|c|c|c|c|c|c|}
\hline $\mathrm{Ca}^{2+}$ & $\mathrm{Mg}^{2+}$ & $\mathrm{Na}^{+}$ & $\mathbf{K}^{+}$ & $\mathrm{Cl}^{-}$ & $\mathrm{pH}$ & EC & Hardness & SAR \\
\hline \multicolumn{6}{|c|}{$\mathrm{mmol} \mathrm{L}^{-1}$} & $\mathrm{dS} \mathrm{m}^{-1}$ & $\mathrm{mg} \mathrm{L}^{-1}$ & \\
\hline
\end{tabular}

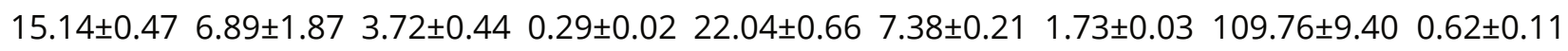

$\mathrm{Ca}=$ calcium; $\mathrm{Mg}=$ magnesium; $\mathrm{Na}=$ sodium; $\mathrm{K}=$ potassium; $\mathrm{Cl}=$ chloride; $\mathrm{pH}=$ hydrogenionic potential; $\mathrm{EC}=$ electrical conductivity; $\mathrm{SAR}=$ sodium adsorption ratio

\section{Irrigations}

Irrigation was carried out three times a week (Monday, Wednesday and Friday), by emitters with a flow rate of $0.9 \mathrm{~L} \mathrm{~h}^{-1}(100 \mathrm{kPa})$, spaced $0.20 \mathrm{~m}$ apart. Irrigation events were carried out in a drip system with a uniformity coefficient of $93 \%$ and considering the location coefficient as a function of the percentage of wet area, as suggested by Montovani et al. ${ }^{(26)}$. As the treatments consisted of different irrigation depths based on crop evapotranspiration, no salt leaching slides were adopted.

Irrigation depths equivalent to $25,50,75$ and $100 \%$ crop evapotranspiration during the 63 days before the first cut were 50.00, 82.00, 114.00, $146.00 \mathrm{~mm}$, respectively, and along the 46 days preceding the second cut, the depths applied were $40.00 ; 80.00$; 120.00 and $161.00 \mathrm{~mm}$ The water depth applied by irrigation totaled $90 \mathrm{~mm}(0.82 \mathrm{~mm}$ $\left.\mathrm{d}^{-1}\right), 162 \mathrm{~mm}\left(1.48 \mathrm{~mm} \mathrm{~d}^{-1}\right), 234 \mathrm{~mm}\left(2.1 \mathrm{~mm} \mathrm{~d}^{-1}\right)$ and $\left.307 \mathrm{~mm}^{2} .81 \mathrm{~mm} \mathrm{~d}^{-1}\right)$ for treatments of $25,50,75$ and $100 \%$ reference evapotranspiration, respectively.

\section{Organic fertilizer}

The organic fertilizer used was a cattle and goat manure previously tanned; this organic mixture has the following characteristics: dry matter $=73.88 \%$ on natural matter, electrical conductivity $=12.27 \mathrm{dS} \mathrm{m} \mathrm{m}^{-1}, \mathrm{pH}=8.3$; phosphorus $=355.39 \mathrm{cmolc} \mathrm{dm}^{-3}$; potassium $=243.5 \mathrm{cmolc} \mathrm{dm}^{-3}$; sodium $=20.3 \mathrm{cmolc} \mathrm{dm}^{-3}$; calcium $=6.4 \mathrm{cmolc} \mathrm{dm}^{-3}$, magnesium $=2.5 \mathrm{cmolc} \mathrm{dm}^{-3}$, copper $=1.45 \mathrm{mg} \mathrm{dm}^{-3}$, iron $=5.36 \mathrm{mg} \mathrm{dm}^{-3}$, manganese $=58.13 \mathrm{mg} \mathrm{dm}^{-3}$ and zinc $=2.43 \mathrm{mg} \mathrm{dm}^{-3}$.

Nitrogen fertilization was applied with $50 \mathrm{~kg} \mathrm{ha}^{-1} \mathrm{~N}$, as urea; the first at sowing, with 20 $\mathrm{kg} \mathrm{ha}^{-1} \mathrm{~N}$, surface broadcast, and the second at 20 days after sowing, with $30 \mathrm{~kg} \mathrm{ha}^{-1} \mathrm{~N}$

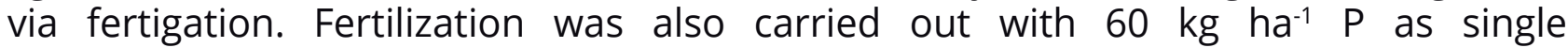
superphosphate and with $20 \mathrm{~kg} \mathrm{ha}^{-1} \mathrm{~K}$, as potassium chloride.

Organic fertilizer was applied by hand in the subplots, according to predetermined levels.

\section{Analysis}

After the end of the vegetative cycle (109 days), soil was collected in duplicate and homogenized to form composite samples by subplot in the layers of $0-0.20$ and 0.20-0.40 m close to the roots of the plants, using a Dutch auger (TF-20, SONDATERRA ${ }^{\circledR}$, São Paulo, Brazil) to assess the following chemical parameters: $\mathrm{pH}$ and electrical conductivity(27), concentrations of potassium (K), calcium (Ca), magnesium (Mg), sodium 
$(\mathrm{Na})$ and aluminum $(\mathrm{Al})^{(28)}$, sum of bases (SB), cation exchange capacity (CEC), base saturation $(\mathrm{V})$ and exchangeable acidity $(\mathrm{H}+\mathrm{Al})^{(29)}$.

Undisturbed soil samples were collected with volumetric cylinders $(0.03 \times 0.05 \mathrm{~m})$ in the 0-0.20 and $0.20-0.40$ m layers to assess the following physical parameters: soil bulk density, particle density and porosity according to Claessen ${ }^{(30)}$.

\section{Statistical analysis}

Data were analyzed in Statistical Analysis System 9.1 (SAS Institute, Cary, NC, EUA). All variables analyzed were tested by analysis of variance, considering significant values those with $P<0.05$, using Tukey's test. For the experiment, the statistical model was calculated according to the equation:

$Y i j=\mu+S i+E j+B I+S i E j+" i j k$

where:

Yij = observed value for irrigation level (i) and organic fertilizer level (j);

$\mu=$ overall constant for all observations;

$\mathrm{Si}=$ effect of the $\mathrm{i}$-th irrigation level, where $\mathrm{i}=1-4$;

$\mathrm{Ej}=$ effect of the $\mathrm{j}$-th organic fertilizer levels, where $\mathrm{j}=1-4$;

$\mathrm{BI}=$ block effect;

$\mathrm{SiEj}=$ effect of the interaction of the $\mathrm{i}$-th irrigation level and the $\mathrm{j}$-th organic fertilizer level; and,

"ijk = random error associated with each observation.

When the effect was isolated, the following statistical model was adopted:

$Y=\alpha+\beta+e$

where:

$\mathrm{Y}$ is the measured variable;

$\alpha$ is the fixed effect of treatment;

$\beta$ is the random effect of block;

" $\mathrm{e}$ " is the residual error.

The interaction was broken down when the studied characteristics showed a significant effect of interaction of the factors using Tukey's test at $5 \%(P<0.05)$. A regression analysis was run when there was an isolated effect of the irrigation or organic fertilizer. The criteria for choosing the regression models (linear or quadratic) were the significance of the parameters estimated by the models and the coefficients of determination $\left(R^{2}\right)$. The standard error of the mean was obtained from the raw data. The PROC REG was used for regression analysis, considering significant values of probability those with $\mathrm{P}<0.05$. 


\section{Results and discussion}

There was no effect of interaction of brackish water levels and organic fertilizer levels on soil chemical properties ( $P>0.05$; Table 3 ). Also, there was no isolated effect of brackish water levels and organic fertilizer levels on soil chemical properties in the 0-20 $m$ layer under pearl millet cultivation ( $P>0.05$; Table 3$)$. The different levels of organic fertilizer did not alter soil chemical properties in the 0.20-0.40 m layer $(P>0.05$; Table $3)$. A reduction was found for $\mathrm{K}^{+}$content in the soil irrigated with brackish water at the 0-0.40 m layer ( $P=0.03$; Table 3).

Table 3. Mean values of chemical properties of soil grown with pearl millet as a function of different levels of irrigation with brackish water and organic fertilizer

\begin{tabular}{|c|c|c|c|c|c|c|c|c|c|c|c|c|c|}
\hline \multirow{3}{*}{ Itens } & \multirow{2}{*}{\multicolumn{4}{|c|}{$\begin{array}{c}\text { Irrigation Level } \\
\text { (\% evapotranspiration) }\end{array}$}} & \multicolumn{6}{|c|}{ Organic fertilizer } & \multirow{2}{*}{\multicolumn{3}{|c|}{ P-value }} \\
\hline & & & & & \multirow[t]{2}{*}{ SEM } & \multicolumn{4}{|c|}{$\left(M^{\prime} a^{-1}\right)$} & \multirow[t]{2}{*}{ SEM } & & & \\
\hline & 25 & 50 & 75 & 100 & & 0 & 15 & 30 & 45 & & $\mathbf{I}$ & OF & I*OF \\
\hline \multicolumn{14}{|c|}{$0-0.20 \mathrm{~m}$} \\
\hline EC & 1.99 & 2.10 & 2.29 & 1.87 & 0.24 & 2.48 & 1.96 & 1.79 & 2.02 & 0.24 & 0.66 & 0.24 & 0.52 \\
\hline $\mathrm{pH}$ & 7.10 & 7.01 & 6.85 & 7.07 & 0.10 & 6.89 & 7.10 & 7.00 & 7.04 & 0.17 & 0.36 & 0.57 & 0.83 \\
\hline $\mathrm{K}^{+}$ & 0.06 & 0.11 & 0.13 & 0.08 & 0.02 & 0.09 & 0.08 & 0.10 & 0.11 & 0.02 & 0.31 & 0.86 & 0.65 \\
\hline $\mathrm{Na}^{+}$ & 0.14 & 0.15 & 0.18 & 0.13 & 0.03 & 0.15 & 0.16 & 0.13 & 0.17 & 0.03 & 0.60 & 0.73 & 0.61 \\
\hline $\mathrm{Ca}^{2+}$ & 5.31 & 5.80 & 4.90 & 5.44 & 0.51 & 5.75 & 5.88 & 4.96 & 4.85 & 1.02 & 0.66 & 0.38 & 0.96 \\
\hline $\mathrm{Mg}^{2+}$ & 1.68 & 1.95 & 1.78 & 1.85 & 0.22 & 2.19 & 1.90 & 1.58 & 1.60 & 0.44 & 0.84 & 0.18 & 0.48 \\
\hline $\mathrm{H}+\mathrm{Al}$ & 0.19 & 0.27 & 0.39 & 0.31 & 0.08 & 0.41 & 0.13 & 0.38 & 0.24 & 0.08 & 0.46 & 0.11 & 0.09 \\
\hline SB & 7.21 & 8.04 & 7.00 & 7.52 & 0.72 & 8.20 & 8.04 & 6.78 & 6.75 & 1.44 & 0.75 & 0.33 & 0.88 \\
\hline CEC & 7.41 & 8.31 & 7.39 & 7.84 & 0.69 & 8.63 & 8.17 & 7.17 & 6.98 & 0.69 & 0.76 & 0.29 & 0.87 \\
\hline V & 97.33 & 96.25 & 94.25 & 95.53 & 1.21 & 94.55 & 98.39 & 94.37 & 96.04 & 2.42 & 0.34 & 0.09 & 0.17 \\
\hline \multicolumn{14}{|c|}{$0.20-0.40 \mathrm{~m}$} \\
\hline EC & 2.38 & 2.60 & 2.83 & 3.00 & 0.25 & 2.81 & 2.56 & 2.64 & 2.79 & 0.50 & 0.34 & 0.87 & 0.31 \\
\hline $\mathrm{pH}$ & 5.85 & 5.97 & 5.60 & 5.95 & 0.18 & 6.01 & 5.51 & 5.85 & 6.00 & 0.36 & 0.44 & 0.20 & 0.06 \\
\hline $\mathrm{K}^{+}$ & 0.15 & 0.15 & 0.06 & 0.01 & 0.03 & 0.09 & 0.10 & 0.08 & 0.10 & 0.07 & 0.03 & 0.96 & 0.86 \\
\hline $\mathrm{Na}^{+}$ & 0.16 & 0.19 & 0.11 & 0.02 & 0.04 & 0.12 & 0.15 & 0.10 & 0.10 & 0.08 & 0.06 & 0.80 & 0.80 \\
\hline $\mathrm{Ca}^{2+}$ & 3.65 & 3.75 & 3.75 & 4.21 & 0.34 & 3.95 & 3.48 & 3.78 & 4.15 & 0.69 & 0.66 & 0.57 & 0.08 \\
\hline $\mathrm{Mg}^{2+}$ & 1.70 & 2.05 & 1.90 & 2.00 & 0.13 & 1.85 & 2.05 & 1.70 & 2.07 & 0.26 & 0.27 & 0.15 & 0.43 \\
\hline $\mathrm{Al}$ & 0.03 & 0.01 & 0.08 & 0.02 & 0.01 & 0.02 & 0.06 & 0.05 & 0.02 & 0.01 & 0.53 & 0.13 & 0.07 \\
\hline $\mathrm{H}+\mathrm{Al}$ & 1.20 & 1.26 & 1.57 & 1.20 & 0.24 & 0.78 & 1.70 & 1.55 & 1.20 & 0.24 & 0.65 & 0.05 & 0.79 \\
\hline SB & 5.67 & 6.11 & 5.80 & 6.23 & 0.41 & 6.00 & 5.76 & 5.64 & 6.41 & 0.82 & 0.75 & 0.57 & 0.09 \\
\hline CEC & 6.89 & 7.39 & 7.42 & 7.46 & 0.37 & 6.80 & 7.50 & 7.23 & 7.64 & 0.37 & 0.66 & 0.41 & 0.11 \\
\hline V & 83.06 & 83.94 & 77.68 & 82.13 & 0.74 & 88.05 & 77.17 & 78.32 & 83.26 & 3.31 & 0.55 & 0.10 & 0.54 \\
\hline 71 & 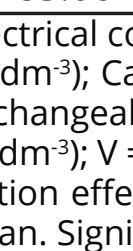 & 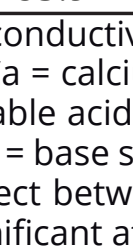 & . & - & 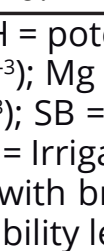 & . & . & 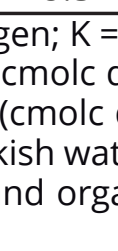 & 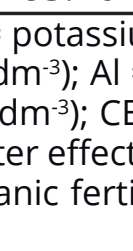 & . & . & ); $\mathrm{Na}=$ & sodium \\
\hline
\end{tabular}


Brackish water levels reduced the $\mathrm{K}+$ content in the $0.20-0.40 \mathrm{~m}$ layer ( $\mathrm{P}=0.03$; Table 3 ),

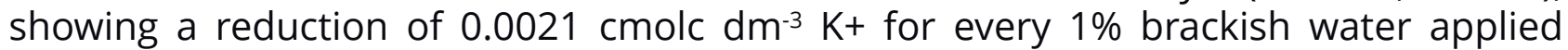
(Figure 3 ). This effect may be related to a reduction in the combination of $\mathrm{K}^{+}$with chloride anion, as this bond promotes a neutral charge compound(31) which, possibly, promoted potassium leaching to lower layers. According to Hasanuzzaman et al.(32) potassium participates in metabolic reactions that provide better tolerance of the plant to adverse conditions, such as water and salt stress.

The use of organic fertilizers reduces the electrical conductivity of the soil, sodium adsorption rate (SAR) and $\mathrm{pH}$, and increases the content of nitrogen, available phosphorus and potassium, which neutralize the effects of irrigation with brackish water ${ }^{(33)}$ contributing to the findings of this study, such that the use of brackish water reduced the potassium content, while the use of organic fertilizer did not change the $\mathrm{K}^{+}$ in soil. Another important factor is that organic fertilization results in improved microbial metabolic activity and nutrient cycling in the rhizosphere ${ }^{(34)}$. In addition to being a rich source of carbon, it provides improvements in soil quality under brackish water irrigation $^{(35)}$.

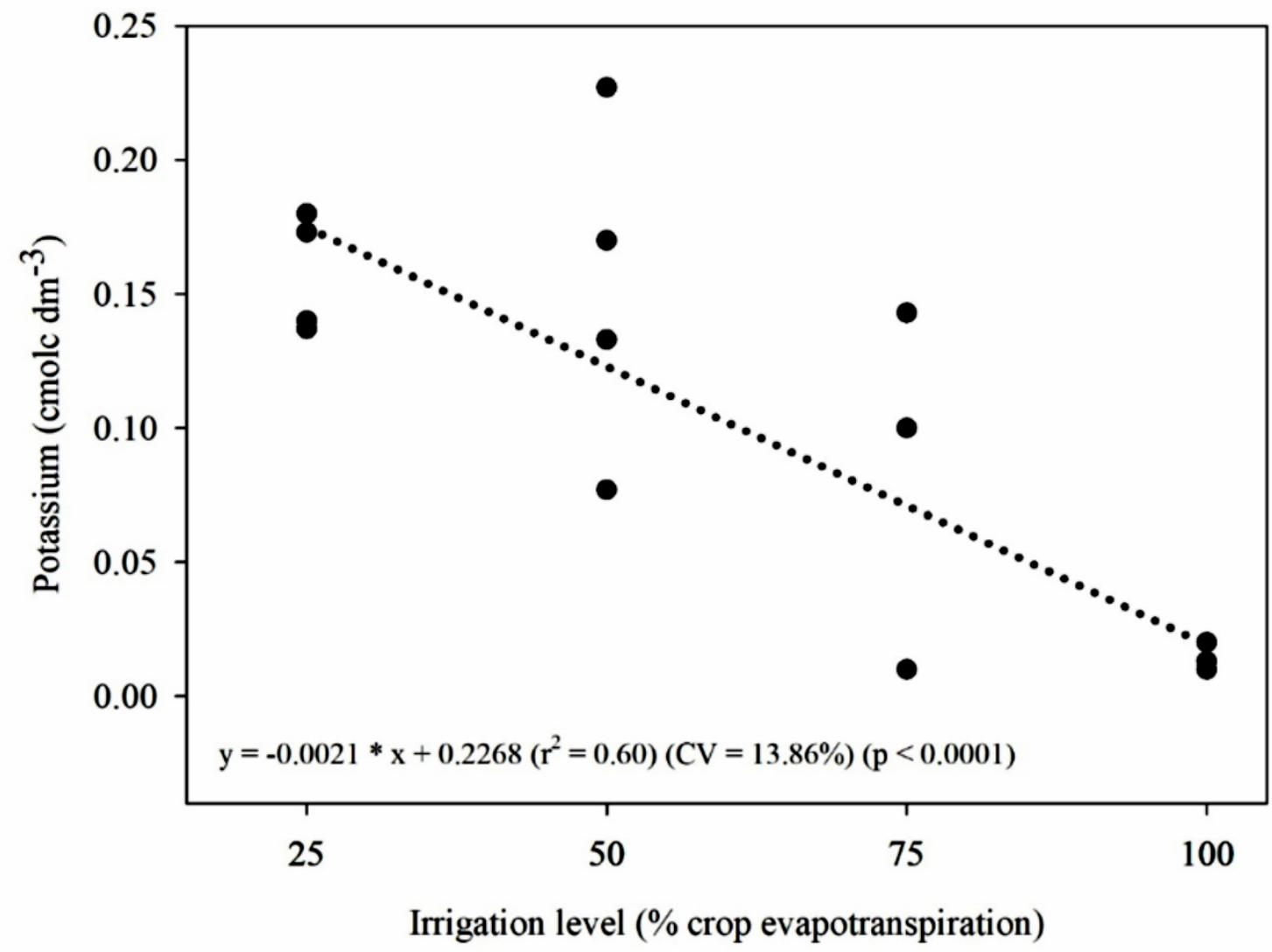

Figure 3. Effect of irrigation level with brackish water on the potassium content in the $0-0.40 \mathrm{~m}$ layer ( ${ }^{*}$ Significant at $p \leq 0.05 ; r^{2}$ - Coefficient of correlation)

Aluminum was not found in the $0-20 \mathrm{~cm}$ layer, however, in the $20-40 \mathrm{~cm}$ layer, this element was registered with contents ranging from 0.01 to $0.08 \mathrm{cmolc} \mathrm{dm}^{-3}$ for brackish water and from 0.02 to $0.06 \mathrm{cmolc} \mathrm{dm}^{-3}$ for the levels of organic fertilizer ( $\mathrm{P}>0.05$; Table 
3). The use of organic fertilizer increases the stocks of organic carbon in the soil, favoring rooting, reducing the toxic effects of aluminum and with beneficial action on the biological activity of the soil $(36,37)$.

Results of $\mathrm{pH}$ and $\mathrm{EC}$ indicate that there was no accumulation of salts in the soil. This possibly because the increase in $\mathrm{pH}$ and $\mathrm{EC}$ are indicative of chemical reactions of salt retention and precipitation in the upper layer through the evaporation process $\mathrm{s}^{(38,39)}$. In arid and semi-arid regions, with a natural drainage system, it is necessary to apply more water than necessary for the crop, in order to leach excess salts from the irrigation water. Possibly, the pluviometric conditions $(140 \mathrm{~mm})$ of the present study was essential for partial leaching of salts from the soil, not changing the EC.

The levels of brackish water and organic fertilizer did not change soil density and soil porosity at a depth of 0-0.20 m ( $P>0.05$; Table 4). The water levels used caused no negative effects on the soil, given that the process of accumulation of salts promotes soil disruption, leading to increased density ${ }^{(40)}$. The presence of salts, such as $\mathrm{Na}^{+}$, degrade the physical structure of the soil by reducing its porosity ${ }^{(41)}$. Rezaei et al. ${ }^{(42)}$ states that soil density increases as the proportion of sand increases, however, this effect was not observed in this study, since brackish water did not influence soil density.

Table 4. Mean values of the physical properties of soil grown with pearl millet as a function of different levels of irrigation with brackish water and organic fertilizer

\begin{tabular}{|c|c|c|c|c|c|c|c|c|c|c|c|c|c|}
\hline \multirow{3}{*}{ Itens } & \multirow{2}{*}{\multicolumn{4}{|c|}{$\begin{array}{c}\text { Irrigation Level } \\
\text { (\% evapotranspiration) }\end{array}$}} & \multirow{3}{*}{ SEM } & \multicolumn{4}{|c|}{ Organic fertilizer } & \multirow{3}{*}{ SEM } & \multirow{2}{*}{\multicolumn{3}{|c|}{ P-value }} \\
\hline & & & & & & & (Mg & $\left.h a^{-1}\right)$ & & & & & \\
\hline & 25 & 50 & 75 & 100 & & 0 & 15 & 30 & 45 & & I & OF & $1 * O F$ \\
\hline \multicolumn{14}{|c|}{$0-0.20 \mathrm{~m}$} \\
\hline D & 1.34 & 1.32 & 1.33 & 1.33 & 0.02 & 1.34 & 1.33 & 1.32 & 1.32 & 0.02 & 0.82 & 0.91 & 0.13 \\
\hline$P$ & 47.52 & 48.04 & 48.14 & 48.39 & 0.83 & 47.84 & 47.81 & 48.53 & 47.92 & 0.83 & 0.90 & 0.92 & 0.30 \\
\hline PD & 2.56 & 2.54 & 2.56 & 2.58 & 0.02 & 2.57 & 2.55 & 2.57 & 2.55 & 0.01 & 0.45 & 0.68 & 0.39 \\
\hline \multicolumn{14}{|c|}{$0.20-0.40 \mathrm{~m}$} \\
\hline D & 1.35 & 1.36 & 1.36 & 1.33 & 0.01 & 1.37 & 1.35 & 1.35 & 1.33 & 0.03 & 0.39 & 0.04 & 0.54 \\
\hline$P$ & 2.47 & 2.63 & 2.51 & 2.55 & 0.07 & 2.57 & 2.51 & 2.55 & 2.53 & 0.08 & 0.46 & 0.94 & 0.46 \\
\hline PD & 43.90 & 47.98 & 45.13 & 47.44 & 2.04 & 46.35 & 45.34 & 46.81 & 45.95 & 2.09 & 0.45 & 0.96 & 0.41 \\
\hline
\end{tabular}

$\mathrm{D}=$ Density; $\mathrm{P}=$ Porosity; $\mathrm{PD}=$ Particle density; soil density $\left(\mathrm{kg} \mathrm{dm}^{-3}\right)$; Porosity (\%); particle density $\left(\mathrm{kg} \mathrm{dm}^{-3}\right)$; I= Irrigation with brackish water effect; $\mathrm{OF}=$ Organic fertilizer; $\mid * \mathrm{OM}=$ Interaction effect between irrigation with brackish water and organic fertilizer; SEM= standard error of the mean; Significant at the 5\% probability level

Isolated effect of organic fertilization levels was observed for soil density $(P=0.04$; Table 4) in layer 0.20-0.40 $\mathrm{m}$, which significantly reduced with increasing organic fertilizer levels. Figure 4 illustrates the reduction in soil density by $1.3733 \mathrm{~kg} \mathrm{dm}^{-3}$ for each $1 \%$ organic fertilizer applied to the soil. The soil physical structure can be altered by organic fertilizer, promoting a change in the angulation of internal friction, which can influence 
directly (decreased friction between mineral particles) or indirectly (modification of soil structure and density) $)^{(43,44)}$. Braida et al. ${ }^{(44)}$ when discussing organic fertilizers and their effect on soil physics, state that this is a beneficial effect as they promote better soil structure, leading to better infiltration, water retention capacity, increase cohesion between soil particles and soil aeration.

It was expected that there would be a significant effect of organic fertilization in the 0-0.20 m layer, as it is more superficial, however, according to Carmo et al.(45), the use of organic fertilizers results in higher activity of edaphic organisms, which work in decomposition of organic matter and incorporation of nutrients in deeper layers of the soil. Organisms between 0.2 and $2 \mathrm{~mm}$ in length (mesofauna) act in the first $5 \mathrm{~cm}$ soil, favoring decomposition, nutrient cycling and soil aggregation ${ }^{(46,47)}$. In deeper layers, organisms with a body diameter larger than $2 \mathrm{~mm}$ (macrofauna - earthworms, termites and ants) act in the physical, chemical and microbiological structuring of soils $s^{(48)}$, and due to aeration through the formation of galleries and incorporation of organic matter in deeper layers, possibly promoted a reduction in soil density in the present study.

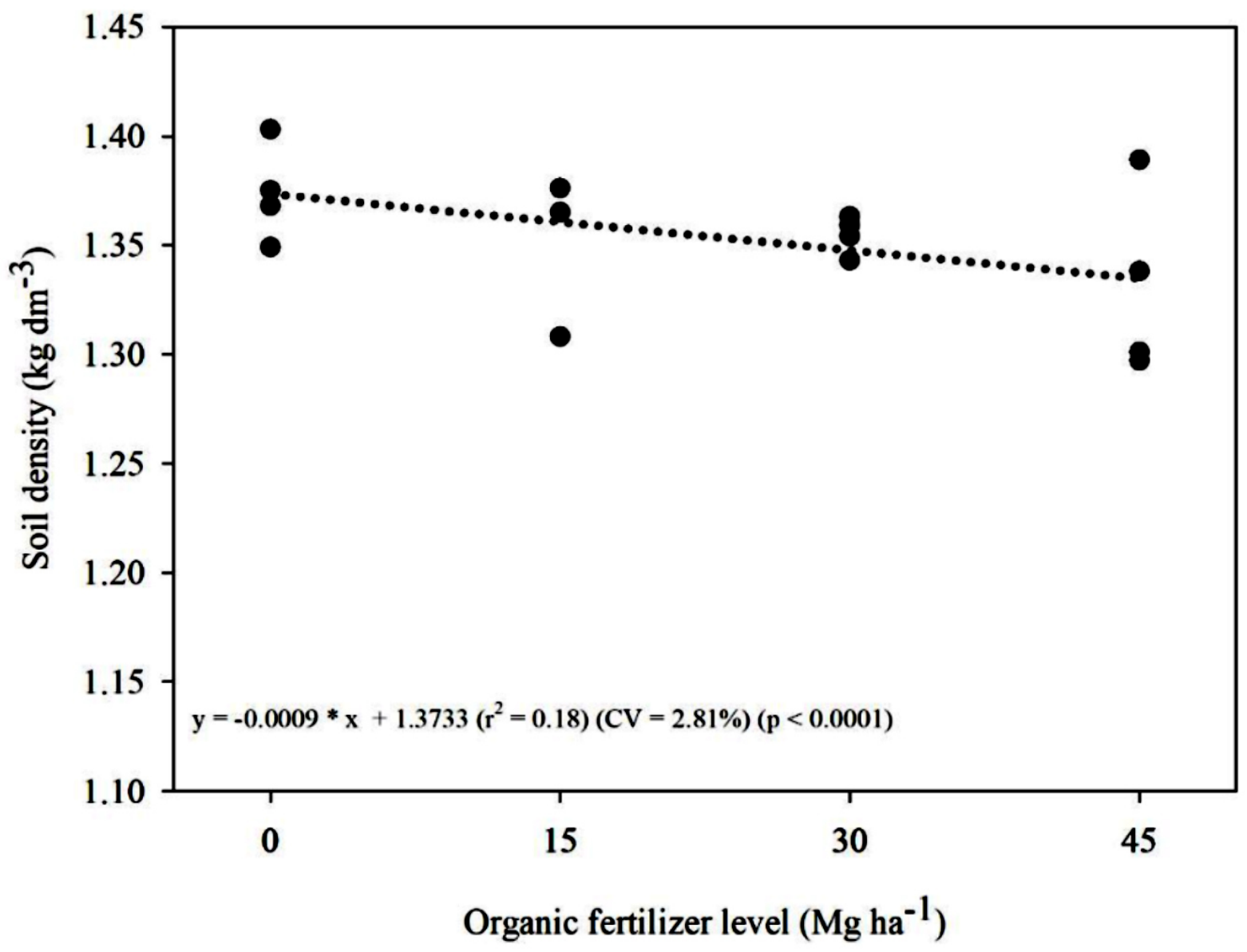

Figure 4. Effect of organic fertilizer on soil density in the $0.20-0.40 \mathrm{~m}$ layer (*Significant at $p \leq 0.05 ; r^{2}$ - Cofficient of correlation) 
Possibly, the action of pearl millet roots may have contributed to reduce density in the deepest layer (0-20-0.40 m), improving the physical quality of the soil. In addition, roots promote the approximation and cohesion of soil particles by exerting biophysical pressures (axial and radial), and also by drying the region adjacent to the roots, resulting in a soil with greater flocculation. Under these conditions, the proportion of macroaggregates will be greater than microaggregates, consequently increasing macroporosity and reducing compaction(49).

\section{Conclusions}

Brackish water levels and organic fertilizer levels in the cultivation of pearl millet do not alter soil chemical and physical properties at the 0-0.20 m layer. However, irrigation with brackish water reduces the potassium concentration in the soil and the application of organic fertilization results in a slight reduction in soil density in the $0.20-0.40 \mathrm{~m}$ layer.

\section{Conflicts of interest}

The authors declare no conflicts of interest.

\section{Acknowledgments}

To the National Council for Scientific and Technological Development (CNPq), for the granting of the Corporate Post-Doctorate scholarship (PDI; Process 316646/2020-2), and the Brazilian Agricultural Research Corporation (EMBRAPA Semiarid).

\section{References}

1.Magalhães ALR, Sousa DR, Nascimento Júnior JRS, Gois GC, Campos FS, Santos KC, Nascimento DB, Oliveira LP. Intake, digestibility and rumen parameters in sheep fed with common bean residue and cactus pear. Biol. Rhyt. Res. 2019; 52(1):1-10. Available on: https://doi.org/ 10.1080/09291016.2019.1592351.

2. Silva FJBC, Azevedo JRG. Temporal trend of drought and aridity indices in semi-arid pernambucano to determine susceptibility to desertification. Braz. J. Water Res. 2020; 25(e32):1-18. Available on: https:// doi.org/10.1590/2318-0331.252020190145.

3. Cavalcante ES, Lacerda CF, Costa RNT, Gheyi HR, Pinho LL, Bezerra FMS, Oliveira AC, Canjá JF. Supplemental irrigation using brackish water on maize in tropical semi-arid regions of Brazil: yield and economic analysis Sci. Agric. 2021; 78(e20200151):1-9. Available on: https://doi.org/ 10.1590/1678-992X-2020-0151.

4. Silva AJ, Aguiar Netto AO, Lucas AAT, Araújo RR, Sousa AF. Reduction of salinity and sodicity of salinesodic soils under filed condition in Brazilian semi-arid region. Scient. Plena. 2020; 16(9):1-14. Available on: https://doi.org/10.14808/sci.plena.2020.090203.

5. Haj-Amor Z, Hashemi H, Bouri S. The consequences of saline irrigation treatments on soil physicochemical characteristics. Euro-Med. J. Env. Int. 2018; 3(22):1-12. Available on: https://doi.org/ 10.1007/s41207-018-0064-y.

6. Tedeschi A. Irrigated agriculture on saline soils: A perspective. Agron. 2020; 10(11):1-6. Available on: https://doi.org/10.3390/agronomy10111630. 
Pearl millet cultivation with brackish water and organic fertilizer alters soil properties Araújo C.A. et al.

7. Acosta-Motos JR, Ortuño MF, Bernal-Vicente A, Diaz-Vivancos P, Sanchez-Blanco MJ, Hernandez JA. Plant responses to salt stress: Adaptive mechanisms. Agron. 2017; 7(1):1-38, 2017. Available on: https:// doi.org/10.3390/agronomy7010018.

8. Arora S, Singh AK, Singh YP. Bioremediation of salt affected soils: An Indian perspective, 1 st ed. Switzerland: Springer Nature; 2017. 313p.

9. Adeleke R, Nwangburuka C, Oboirien B. Origins, roles and fate of organic acids in soils: A review. South Afr. J. Bot. 2017; 108(1):393-406. Available on: https://doi.org/10.1016/j.sajb.2016.09.002.

10. Souza MCMR, Menezes A, Costa RS, Amorim AV, Lacerda CF. Tolerância à salinidade e qualidade de mudas de noni sob diferentes ambientes e matéria orgânica. Rev. Bras. Agric. Irrig. 2017a; 11(7):2052-2062. Available on: https://doi.org/10.7127/rbai.v11n700682.

11. Leal YH, Dias TJ, Bezerra AC, Leal MPS, Lopes AS, Moura JG, Ribeiro JES, Souza AG. Application times and doses of bovine and sheep biofertilizers in the morphophysiological characteristics of green pepper plants. Scientia Plena, VOL. 16, NUM. 9, 1-10. 2020. Available on: https://doi.org/10.14808/ sci.plena.2020.090202.

12. Zhang Z, Zhang Z, Lu P, Feng G, Qi W. Soil water-salt dynamics and maize growth as affected by cutting length of topsoil incorporation straw under brackish water irrigation. Agron. 2020; 10(2):1-17. Available on: https://doi.org/10.3390/agronomy10020246.

13. Silva AJ, Aguiar Netto AO, Lucas AAT, Araújo RR, Sousa AF. Reduction of salinity and sodicity of salinesodic soils under filed condition in Brazilian semi-arid region. Sci. Plena. 2020; 16(9):1-14. Available on: https://doi.org/10.14808/sci.plena.2020.090203

14. Souza LP, Lima GS, Gheyi HR, Nobre RG, Soares LAA. Emergence, growth, and production of colored cotton subjected to salt stress and organic fertilization. Rev. Caat. 2018; 31(3): 719-729. Available on: https://doi.org/10.1590/1983-21252018v31n322rc.

15. Souza LP, Nobre RG, Barbosa JL, Lima GS, Almeida LLS, Pinheiro FW. Cultivo do algodoeiro CV. BRS Topázio em solos salino-sódico com adição de matéria orgânica. Rev. Espacios. 2017b; 38(14):1-12. Available on: https://www.revistaespacios.com/a17v38n14/a17v38n14p18.pdf.

16. Lira JB, Andrade AP, Magalhães ALR, Campos FS, Araújo GGL, Deon DS, Gois GC, Regitano Neto A, Cunha DS, Tabosa JN, Silva TGF, Nagahama HJ. Production of Pearl millet irrigated with different levels of saline water and organic matter. Commun. Soil Sci. Plant An. 2020; 51(5):701-709. Available on: https:// doi.org/10.1080/00103624.2020.1729794.

17. Moura MMA, Pires DAA, Jayme DG, Costa RF, Rigueira JPS, Rodrigues JAS. Agronomic performance and nutritive value of millet silages. Acta Scient. An. Sci. 2018; 40(e34430):1-6. Available on: https://doi.org/ 10.4025/actascianimsci.v40i1.34430.

18. Iwuala EN, Odjegba VJ, Sharma V, Alam A. Highlights of strategies adapted by two Pennisetum glaucum (L.) R. Br. races in a simulated drought stress experiment. Plant Gen. 2020; 23(1):1-34. Available on: https:/ /doi.org/10.1016/j.plgene.2020.100238.

19. Cosgrove WJ, Loucks DP. Water management: current and future challenges and research directions. Water Resour. Res. 2015; 51(6):4823-4839. Available on: https://doi.org/10.1002/2014WR016869.

20. Makarana G, Kumar A, Yadav RK, Kumar R, Soni PG, Lata C, Sheoran P. Effect of saline water irrigations on physiological, biochemical and yield attributes of dual purpose pearl millet (Pennisetum glaucum) varieties. Indian J. Agric. Sci. 2019; 89(4):624-633. Available on:

https://www.researchgate.net/publication/

330041855 Effect of saline water irrigations on physiological biochemical and yield attributes of du al purpose pearl millet Pennisetum glaucum L varieties.

21. Köppen W, Geiger RG. Klimate der Erde. Gotha: Verlag Justus Perthes, Wall-map $150 \mathrm{~cm} \times 200 \mathrm{~cm}$. 1928. 
Pearl millet cultivation with brackish water and organic fertilizer alters soil properties Araújo C.A. et al.

22. Santos HG, Jacomine PKT, Anjos LHC, Oliveira VA, Lumbreras JF, Coelho MR, Almeida JA, Araújo Filho JC, Oliveira JB, Cunha TJF. Sistema brasileiro de classificação de solos, 5th ed. Brasília: Embrapa; 2018. 356p. Available on: https://www.embrapa.br/solos/sibcs.

23. Allen RG, Pereira LS, Raes D, Smith M. Crop evapotranspiration: Guidelines for computing crop water requirements. Roma, 56, Food and Agriculture Organization, Drainage and Irrigation Paper; 1998. 300p. Available on: http://www.fao.org/3/x0490e/x0490e00.htm.

24. Lima JGA. Necessidades hídricas do Sorgo de pura aptidão sob condições irrigadas na chapada do Apodi. [dissertação]. Mossoró: Universidade Federal Rural do Semi-Árido; 2013. 74 p.

25. Richards LA. Diagnosis and improvement of saline and alkali soils, 1st ed. Washington D.C.: Agriculture Handbook; 1954. 166p.

26. Montovani EC, Bernardo S, Palaretti LF. Irrigação - princípios e métodos, 1st ed. Viçosa: Editora UFV; 2006. 318p.

27. Aoac. Association of Official Analytical Chemists. Official methods of analysis, 20th ed. Washington, D.C.: Latimer Jr., G.W.; 2016. 3172p.

28. Holanda Filho RSF, Santos DB, Azevedo CAV, Coelho EF, Lima VLA. Água salina nos atributos químicos do solo e no estado nutricional da mandioqueira. Rev. Bras. Eng. Agric. Amb. 2011; 15(1):60-66. Available on: https://doi.org/10.1590/S1415-43662011000100009.

29. Coldebella N, Lorenzetti E, Tartaro J, Treib EL, Pinto RE, Fontana A, Alves AB. Desempenho do milho à elevação da participação do cálcio na CTC. Scient. Agr. Paranaensis. 2018; 17(4):443-450. Available on: http://e-revista.unioeste.br/index.php/scientiaagraria/article/view/20230.

30. Claessen MEC. Manual de métodos de análise de solo, 2nd ed. Rio de Janeiro: Embrapa-CNPS; 1997. 212p.

31. Tränkner M, Tavakol E, Jákli B. Functioning of potassium and magnesium in photosynthesis, photosynthate translocation and photoprotection. Phy. Plant. 2018; 163(3):414-431. Available on: https:/ /doi.org/10.1111/ppl.12747.

32. Hasanuzzaman M, Bhuyan MHMB, Nahar K, Hossain MS, Al Mahmud J, Hossen MS, Masud AAC, Moumita, Fujita M. Potassium: A vital regulator of plant responses and tolerance to abiotic stresses. Agron. 2018; 8(3):1-29. Available on: https://doi.org/10.3390/agronomy8030031.

33. Munir A, Nawaz S, Bajwa MA. Farm manure improved soil fertility in mungbean-wheat cropping system and rectified the deleterious effects of brackish water. Pak. J. Agric. Sci. 2012; 49(4):511-519.

34. Li J, Awasthi MK, Xing W, Liu R, Bao H, Wang X, Wu F. Arbuscular mycorrhizal fungi increase the bioavailability and wheat (Triticum aestivum L.) uptake of selenium in soil. Ind. Crops Prod. 2020; 150(e112383):1-9. Available on: https://doi.org/10.1016/j.indcrop.2020.112383.

35. Yan S, Gao Y, Tian M, Tian Y, Li J. Comprehensive evaluation of effects of various carbon-rich amendments on tomato production under continuous saline water irrigation: Overall soil quality, plant nutrient uptake, crop yields and fruit quality. Agric. Water Man. 2021; 255(e106995): 1-12. Available on: https://doi.org/10.1016/j.agwat.2021.106995.

36. Husniev I, Romanenkov V, Minakova O, Krasilnikov P. Modelling and prediction of organic carbon dynamics in arable soils based on a 62-year field experiment in the Voronezh region, European Russia. Agron. 2020; 10(10):1-16. Available on: https://doi.org/10.3390/agronomy10101607.

37. Mayer M, Prescott CE, Abaker WEA, Augusto L, Cécillon L, Ferreira GWD, James J, Jandl R, Katzensteiner K, Laclau JP, Laganière J, Nouvellon Y, Paré D, Stanturf JA, Vanguelova El, Vesterdal L. Tamm Review: Influence of forest management activities on soil organic carbon stocks: A knowledge synthesis. Forest Ecol. Manag. 2020; 466(e118127):1-25, 2020. Available on: https://doi.org/10.1016/j.foreco.2020.118127. 
38. Xia LI, He KL, Wang ZY, Bai SX. Quantitative trait loci for Asian Corn Borer resistance in maize population Mc37× Zi330. Agric. Sci. China. 2010; 9(1):77-84. Available on: https://doi.org/10.1016/ S1671-2927(09)60070-5.

39. Chachar AN, Mirjat MU, Soothar RK, Shaikh IA, Mirjat MH, Dahri SA. Effects of irrigation frequencies on soil salinity and crop water productivity of fodder maize. Acta Ecol. Sinica. 2020; 40(4):277-282. Available on: https://doi.org/10.1016/j.chnaes.2019.05.013.

40. Sahab S, Suhani I, Srivastava V, Chauhan PS, Singh RP, Prasad V. Potential risk assessment of soil salinity to agroecosystem sustainability: current status and management strategies. Sci. Total Env. 2021; 764(e144164):1-69. Available on: https://doi.org/10.1016/j.scitotenv.2020.144164.

41. Otlewska A, Migliore M, Dybka-Stepien K, Manfredini A, Struszczyk-Swita K, Napoli R, Białkowska A, Canfora L, Pinzari F. When salt meddles between plant,soil, and microorganisms. Front. Plant Sci. 2020; 11(e553087):1-23. Available on: https://doi.org/10.3389/fpls.2020.553087.

42. Rezaei M, Seuntjens P, Shahidi R, Joris I, Boënne W, Al-Barri B, Cornelis W. The relevance of in-situ and laboratory characterization of sandy soil hydraulic properties for soil water simulations. J. Hydro. 2016; 534(1):251-265. Available on: https://doi.org/10.1016/j.jhydrol.2015.12.062.

43. Dias AS, Nobre RG, Lima GD, Gheyi HR, Pinheiro FWA. Crescimento e produção de algodoeiro de fibra colorida cultivado em solo salino-sódico e adubação orgânica. Irriga. 2016; 1(1):260-273. Available on: https://doi.org/10.15809/irriga.2016v1n1p260-273.

44. Braida JA, Bayer C, Albuquerque JA, Reichert JM. Matéria orgânica e seu efeito na física do solo. In: Klauberg Filho O, Mafra Al, Gatiboni LC, editores. Tópicos em ciência do solo, 7th ed. Viçosa, MG: Sociedade Brasileira de Ciência do Solo; 2011. p.221-278. Available on: https://www.researchgate.net/ publication/283498634 Materia organica e seu efeito na fisica do solo.

45. Carmo DL, Lima LB, Silva CA. Soil fertility and electrical conductivity affected by organic waste rates and nutrient inputs. Rev. Bras. Ci. Solo. 2016; 40(e0150152): 1-17. Available on: https://doi.org/ 10.1590/18069657rbcs20150152.

46. Zagatto MRG, Zanão Júnior LA, Pereira APA, Estrada-Bonilla G, Cardoso EJBN. Soil mesofauna in consolidated land use systems: how management affects soil and litter. Sci. Agric. 2019; 76(2): $165-171$. Available on: http://dx.doi.org/10.1590/1678-992X-2017-0139.

47. Haanes H, Gjelsvik R. Reduced soil fauna decomposition in a high background radiation área. PLoS One. 16(3): e0247793. Available on: https://doi.org/10.1371/journal.pone.0247793.

48. Bottinelli N, Jouquet $P$, Capowiez $Y$, Podwojewski P, Grimaldi M, Peng X. Why is the influence of soil macrofauna on soil structure only considered by soil ecologists? Soil Til. Res. 2015; 146(3):118-124. Available on: https://doi.org/10.1016/j.still.2014.01.007.

49. Calonego JC, Raphael JPA, Rigon JPG, Oliveira Neto L, Rosolem CA. Soil compaction management and soybean yields with cover crops under no-till and occasional chiseling. Eur. J. Agron. 2017; 85(1):31-37. Available on: https://doi.org/10.1016/j.eja.2017.02.001. 